\title{
Pengaruh Collaborative Skills dan Kompetensi Pedagogik Guru Terhadap Kinerja Siswa Sekolah Dasar di Gugus 10 Kecamatan Pamulang
}

\author{
Sri Irnaningsih ${ }^{1}$, Udan Kusmawan ${ }^{2}$, Rhini Fatmasari ${ }^{3}$ \\ Program Pendidikan Dasar ${ }^{1}$, Universitas Terbuka ${ }^{2}$ \\ e-mail: sriirnaningsih28@gmail.com, udan@ecampus.ut.ac.id, riens@ecampus.ut.ac.id \\ Received: 04 Januari 2021; Revised: 26 Februari 2021; Accepted: 28 April 2021 \\ DOI: http://dx.doi.org/10.37905/aksara.7.2.523-536.2021
}

\begin{abstract}
Abstrak
Collaborative skills merupakan kompetensi atau keahlian yang harus dimiliki oleh seseorang di abad 21. Sementara itu kompetensi pedagogik merupakan salah satu kompetensi yang wajib dikuasai oleh seorang guru berkenaan dengan karakteristikpeserta didik dilihat dari berbagai aspek fisik, moral, sosial, kultural, emosional, dan intelektual. Oleh karena itu diharapkan kedua hal ini dapat berpengaruh langsung terhadap kinerja siswa. Collaborative skills dan kompetensi pedagogik guru dapat mempengaruhi peningkatan kinerja siswa. Oleh karena itu penelitian ini bertujuan untuk: (1) Mengetahui pengaruh collaborative skills terhadap kinerja siswa; (2) Mengetahui pengaruh kompetensi pedagogik guru terhadap kinerja siswa; dan (3) Mengetahui pengaruh antara collaborative skills dan kompetensi pedagogik guru terhadap kinerja siswa Sekolah Dasar di Gugus 10 Kecamatan Pamulang. Penelitian ini termasuk jenis penelitian deskriptif kuantitatif. Sampel dalam penelitian ini menggunakan metode Purposive Sampling sehingga menghasilkan jumlah sampel sebanyak 48 orang. Alat pengumpul data yang digunakan pada penelitian ini adalah kuesioner. Teknik analisa yang digunakan adalah metode regresi linier berganda. Hasil deskripsi pada penelitian ini menunjukkan bahwa secara parsial (uji t): (1) variabel collaborative skills $\left(\mathrm{X}_{1}\right)$ berpengaruh terhadap kinerja siswa (Y) dengan nilai thitung $=2,233$ atau $22,33 \%$ lebih

besar dibandingkan dengan $t_{\text {tabel }}=2,012$. Artinya, bahwa variabel collaborative skills berpengaruh secara signifikan terhadap kinerja siswa. (2) Variabel kompetensi pedagogik guru berpengaruh terhadap kinerja siswa (Y) dengan nilai $\mathrm{t}_{\text {hitung }}=4,239$ atau $42,39 \%$ lebih besar dari tabel $=2,012$. (3) Hasil uji hipotesis secara simultan (uji F) collaborative skills dan kompetensi pedagogik guru secara bersama-sama berpengaruh terhadap kinerja siswa dengan nilai $F_{\text {hitung }}$ lebih besar dari $\mathrm{F}_{\text {tabel }}$ sebesar 3,20 atau 17, $058>3,20$. Koefisien determinasi (adjused $R^{2}$ ) 0,431 atau 43,1\%, dan sisanya sebesar 56,9\% merupakan kontribusi variabel bebas lainnya.
\end{abstract}

Kata Kunci : collaborative skills, kompetensi pedagogik guru dan kinerja siswa

\begin{abstract}
Collaborative skills are competencies or skills that must be possessed by someone in the 21 st century. Meanwhile, pedagogic competence is one of the competencies that must be mastered by a teacher with regard to the characteristics of learners seen from various aspects of physical, moral, social, cultural, emotional, and intellectual. Therefore, it is expected that these two things can have a direct effect on student performance. Collaborative skills and pedagogic competencies of teachers can affect the improvement
\end{abstract}




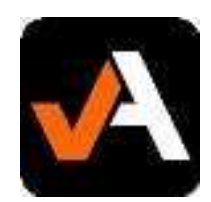

AKSARA: Jurnal Ilmu Pendidikan Nonformal

P-ISSN 2407-8018 E-ISSN 2721-7310 DOI prefix $\underline{10.37905}$

Volume 07 (02) Mei 2021

http://ejurnal.pps.ungac.id/index.php/Aksara

of student performance. Therefore, this study aims to: (1) Know the influence of

collaborative skills on student performance; (2) Knowing the influence of teacher pedagogic competence on student performance; and (3) Knowing the influence between collaborative skills and pedagogic competencies of teachers on the performance of elementary school students in Cluster 10 Pamulang Subdistrict. This research includes a type of quantitative descriptive research. The samples in this study used Purposive Sampling method so as to produce a sample number of 48 people. The data collection tool used in this study was a questionnaire. The analytical techniques used are multiple linear regression methods. The results of the description in this study showed that partially (test $t)$ : (1) variable collaborative skills ( $\left.\mathrm{X}_{1}\right)$ affect the performance of students

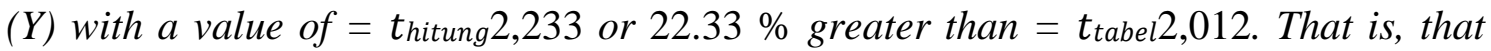
collaborative skills variables significantly affect student performance. (2) The teacher's pedagogic competency variable $\left(\mathrm{X}_{2}\right)$ affects student performance $(Y)$ with a value

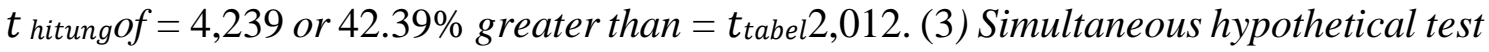
results ( $F$ test) collaborative skills and pedagogic competencies of teachers jointly affect the performance of students with scores $F_{\text {hitunggreater than } F_{\text {tabel }} 3.20 \text { or } 17.058}$ $>3.20$. The coefficient of determination (adjused $R^{2}$ ) 0,431 or $43.1 \%$, and the remaining $56.9 \%$ is the contribution of other free variables.

Keywords: collaborative skills, pedagogic competencies of teachers and student performance.

\section{PENDAHULUAN}

Pendidikan merupakan suatu hal yang sangat penting bagi kehidupan manusia, terutama bagi kemajuan dan perkembangan suatu bangsa untuk membentuk sumber daya manusia yang berilmu pengetahuan tinggi. Pendidikan yang berkualitas tidak lepas dari keberhasilan guru dalam melaksanakan proses pembelajaran di kelas. Guru adalah elemen penting dalam pendidikan. Peranan guru sangat menentukanusaha peningkatan mutu dan kualitas pendidikan bangsa, sehingga sebagai salah satukomponen kunci dalam pendidikan dituntut untuk mampu menyelenggarakan prosespembelajaran dengan sebaik-baiknya untuk mewujudkan kejayaan pembangunan bangsa. Upaya perbaikan peningkatkan kualitas pendidikan tidak akan memberikan sumbangan yang signifikan tanpa didukung oleh guru yang profesional dan berkualitas.Berbagai upaya dalam rangka peningkatkan kualitas pendidikanpun senantiasa dilakukan, disesuaikan dengan perkembangan situasi dan kondisi, serta era yang terjadi. Untukmengajar pada abad ke-21 secara efektif, pemerintah harus mengembangkan guru denganrencana yang kaya akan strategi pembelajaran, dengan pemahaman yang mendalam tentan bagaimana pembelajaran terlaksana, kemampuan untuk bekerjasecara kolaboratif dan keterampilan yang kuat dalam pembelajaran.

Menurut Daryanto dan Syaiful (2017) guru abad 21 diharapkan "mampu dan dapat menyelenggarakan proses pembelajaran yang bertumpu dan melaksanakan empat pilar belajar yang dianjurkan oleh Komisi Internasional UNESCO untuk Pendidikan, yaitu; 1) Learning to know; 2) Learning to do; 3) Learning to be; 4) Learning to live together. Guru dituntut selalu berperan aktif, kreatif, serta tekun (Daryanto, 2017). Menurut " $21^{\text {st }}$ Century Partnership Learning Framework", terdapat sejumlah kompetensi dan/keahlian yang harus dimiliki oleh seseorang di abad-21, yaitu: 1) Kemampuan berpikir kritis dan 
AKSARA: Jurnal Ilmu Pendidikan Nonformal

P-ISSN $\underline{2407-8018}$ E-ISSN $\underline{2721-7310}$ DOI prefix $\underline{10.37905}$

Volume 07 (02) Mei 2021

http://ejurnal.pps.ungac.id/index.php/Aksara

pemecahan masalah (Chritical-Thinking and Problem-Solving Skills), mampu berpikir secara kritis, lateral, sistemik, terutama dalam konteks pemecahan masalah; 2) Kemampuan berkomunikasi dan bekerjasama (Communication and Collaborative Skills) mampu berkomunikasi dan bekerja sama secara efektif dengan berbagai pihak; 3) Kemampuan mencipta dan membaharui (Creatifity and Innovation skills) mampu mengembangkan kreatifitas yang dimilikinya untuk menghasilkan berbagai terobosan yang inovatif; 4) Literasi teknologi informasi dan komunikasi (Information and Communications Technologi Literacy) mampu memanfaatkan teknologi informasi dan komunikasi untuk meningkatkan kinerja dan aktivitas sehari-hari; 5) Kemampuan belajar kontekstual (Contextual Learning Skills) mampu menjalani aktivitas pembelajaran mandiri yang kontekstual sebagai bagian dari pengembangan pribadi; 6) Kemampuan informasi dan literasi media (Information and Media Literasy Skills) mampu memahami dan menggunakan berbagai media komunikasi untuk menyampaikan beragam gagasan dan melaksanakan aktivitas kolaborasi serta interaksi dengan berbagai pihak.

Salah satu keterampilan yang harus dimiliki oleh guru di abad 21 adalah Collaborative Skills. Collaborative Skills are the behaviors that help two or more people work together and function well in the process. Keterampilan kerja sama (Collaborative Skills) adalah merupakan perilaku yang membantu dua orang atau lebih bekerja bersama dan berfungsi dengan baik dalam proses. Kerja sama sangat bergantung pada kemampuan untuk sekedar bergabung, berkomitmen untuk bekerja dengan orang lain, mendengarkan apa yang dikatakan orang lain dan mendorong seseorang untuk berbicara dan memiliki ide atau pendapat. Dalam dunia pendidikan, keterampilan kerja sama harus dilaksanakan dalam pembelajaran, baik di dalam maupun di luar sekolah. Kerja sama dapat mempercepat tujuan pembelajaran, karena pada dasarnya suatu komunitas belajar selalu lebih baik hasilnya daripada sendiri-sendiri (Leonard, 2013).

Di sekolah kolaboratif antara guru dengan siswa dalam proses belajar mengajar seringkali satu arah dimana siswa hanya sekedar mendengarkan apa yang disampaikan guru. Oleh karenanya, siswa lebih dilibatkan secara aktif untuk berinteraksi dengan guru atau antar siswa. Dengan adanya kolaborasi yang baik antara guru dengan siswa maka proses belajar mengajar akan menjadi lebih mudah dilakukan untuk menghasilkan keterampilan yang bisa dikuasai oleh siswa.

Pencapaian keterampilan abad ke-21 tersebut dilakukan dengan memperbarui kualitas pembelajaran, membantu siswa mengembangkan partisipasi, menyesuaikan personalisasi belajar, menekankan pada pembelajaran berbasis proyek/masalah, mendorong kerjasama dan komunikasi, meningkatkan keterlibatan dan motivasi siswa, membudayakan kreativitas dan inovasi dalam belajar, menggunakan sarana belajar yang tepat, mendesaian aktivitas belajar yang relevan dengan dunia nyata, memberdayakan metakognisi, dan mengembangkan pembelajaran student-centered. Berbagai keterampilan abad ke-21 harus secara eksplisit diajarkan.

Pembelajaran abad ke-21 memiliki prinsip pokok bahwa pembelajaran harus berpusat pada siswa, bersifat kolaboratif, kontekstual, dan terintegrasi dengan masyarakat. Peran guru dalam melaksanakan pembelajaran abad ke-21 sangat penting dalam mewujudkan masa depan anak bangsa yang lebih baik.

Untuk mencapai tujuan pembelajaran abad ke-21, salah satu aspek yang penting yaitu assessment atau penilaian. Penilaian dan pembelajaran tidak dapat dipisahkan, keduanya menyatu (integrated). Kualitas pembelajaran yang baik dapat dilihat dari 
kualitas penilaiannya, begitupun sebaliknya kualitas penilaian dapat menunjukkan bagaimana kualitas pembelajarannya. Seorang guru harus mampu merancang sistem penilaian yang bersifat kontinu artinya penilaian dilakukan sejak peserta didik mulai melakukan kegiatan, sedang, dan setelah selesai melaksanakan kegiatannya. Penilaian bisa diberikan kepada siswa sebagai feedback, oleh pendidik dengan rubrik yang telah disiapkan atau berdasarkan kinerja serta produk yang mereka hasilkan. Selain collaborative skills guru faktor penting yang mempengaruhi kinerja siswa adalah kompetensi guru. Undang-Undang Nomor 14 Tahun 2005 tentang Guru dan Dosen, Pasal 10 Ayat 1 menjelaskan, "Kompetensi yang wajib dikuasai oleh guruminimal meliputi kompetensi pedagogik, kompetensi kepribadian, kompetensi sosial, dan kompetensi professional yang diperoleh melalui pendidikan profesi." (Undang-Undang-Nomor-14Tahun-2005.Pdf, 2005).

Guru harus memiliki kompetensi yang memadai untuk mengembangkan peserta didik secara utuh. Kompetensi khusus yang harus dikembangkan berkaitan dengan pengembangan peserta didik adalah kompetensi pedagogik.

Peraturan Pemerintah Republik Indonesia Tahun 2005 tentang Standar Nasional Pendidikan, pasal 28 Ayat (3) butir (a) menjelaskan: Kompetensi pedagogik adalah kemampuan mengelola pembelajaran peserta didik yang meliputi pemahaman terhadap peserta didik. Perancangan pembelajaran, evaluasi hasil belajar, dan perkembangan peserta didik untuk mengaktualisasikan berbagai potensi yang dimilikinya.

Kompetensi pedagogik merupakan kemampuan yang harus dimiliki guru berkenaan dengan karaktersitik peserta didik dilihat dari berbagai aspek baik aspek fisik, moral, sosial, kultural, emosional, dan intelektual. Implikasinya adalah bahwa seorang guru harus mampu menguasai teori belajar dan prinsip-prinsip pembelajaran yang mendidik karena peserta didik memiliki karakter, sifat, dan interes yang berbeda. Berkenaan dengan pelaksanaan kurikulum, guru harus mampu mengembangkan kurikulum di tingkat satuan pendidikan masing-masing.

Pada praktek pembelajaran kompetensi pedagogik ditunjukkan oleh guru dalam bentuk keahliannya dalam: (1) menyusun alat penilaian yang sesuai dengan tujuan pembelajaran yang tertulis dalam RPP, (2) melaksanakan penilaian dengan berbagai teknik dan jenis penilaian, (3) menganalisis hasil penilaian, (4) memanfaatkan masukan dari peserta didik dan merefleksikannya untuk meningkatkan pembelajaran selanjutnya (5) memanfaatkan hasil penilaian sebagai bahan penyusunan rancangan pembelajaran selanjutnya, (6) melakukan penelitian tindakan kelas untuk meningkatkan kualitas pembelajaran. Kinerja menurut Koesmono (2013) adalah suatu gambaran tentang diri seseorang dengan berbagai standar tugas yang telah diberikan kepada orang tersebut sebagai salah satu bentuk tanggung jawab dalam kurun waktu tertentu dan dapat diukur (Koesmono, 2013). Kinerja bukan merupakan karakteristik individu, seperti bakat atau kemampuan, tetapi merupakan perwujudan dari bakat atau kemampuan itu sendiri. Kinerja merupakanperwujudan dari kemampuan dalam bentuk nyata. (Priansa, 2014)

Kinerja siswa adalah kesanggupan siswa untuk dapat menunjukkan penguasaannya atas berbagai tujuan pembelajarannya. Guru harus dapat merumuskan tujuan pembelajaran yang hendak dicapai secara jelas dan dapat mengkomunikasikannya pada 
AKSARA: Jurnal Ilmu Pendidikan Nonformal

P-ISSN 2407-8018 E-ISSN 2721-7310 DOI prefix $\underline{10.37905}$

Volume 07 (02) Mei 2021

http://ejurnal.pps.ungac.id/index.php/Aksara

awal pembelajaran, baik tentang wilayah materi, indikator kurikuler maupun penguasaan tujuan. Menurut Ellis (1998) kinerja siswa merupakan reaksi aktif yang diamati dari responbaik secara langsung atau tidak langsung melalui produk permanen. Kinerja merupakan tingkat keberhasilan dalam melaksanakan tugas serta kemampuan untuk mencapai tujuanyang telah ditetapkan yang dapat mengungkapkan pemahaman tentang konsep danketerampilan melaksanakan tugas.

Dengan demikian kinerja siswa merupakan gambaran kemampuan siswa dalam menyelesaikan tugas-tugas spesifik yang diberikan oleh guru dan dapat diukur berdasarkan kriteria yang ditentukan. Untuk mengukur kemampuan siswa berdasarkan cara siswa menyelesaikan tugas-tugas spesifik bisa diukur dengan penilaian kinerja. Sri Rumini (2004) menyatakan bahwa ada 2 faktor yang mempengaruhi kinerja siswa yaitu faktor dari luar siswa, (meliputi: faktor lingkungan dan faktor instrument) danfaktor dari dalam diri siswa, (meliputi: faktor fisiologis dan faktor psikologis).

Kinerja siswa dapat dinilai dengan penilaian kinerja (performance assessment). Penilaian kinerja harus memenuhi standar penilaian yang tercantum pada Permendikbud Nomor 66 Tahun 2011, yang menegaskan bahwa penilaian harus mengukur semua kompetensi siswa berdasarkan proses dan hasil. Selain itu, penilaian kinerja juga memiliki relevansi yang kuat terhadap pendekatan ilmiah dalam pembelajaran sesuai dengan tuntutan kurikulum 2013 karena mampu menggambarkan peningkatan hasil belajar peserta didik, baik dalam rangka mengobservasi, menalar, mencoba, membangun jejaring, dan lain-lain. (Sulipan, 2013)

Lovell \& Wiles (1983), menyatakan bahwa Colaboration is coope-rating, sharing ideas, solving prob-lems and providing feedback based on observation of teaching, with a person with a person with greather or less influence. (Jhon and Wiles Kimball, 1983). Kolaborasi adalah kerja sama, tukar pendapat, pemecahan masalah dan pemberian umpan balik setelah observasi yang dilakukan oleh orang yang memberikan pengaruh atau tidak memberikan pengaruh dalam meningkatkan proses pembelajaran.

Collaborative Skills are the behaviors that help two or more people work together and function well in the process. Keterampilan kolaboratif adalah perilaku yang membantu dua orang atau lebih bekerja bersama dan berfungsi dengan baik dalam proses.

Collaborative skills allow two or more people to accomplish something with an and result being achieved, ideally, quicker and/or better than if one person was traying to do it alone. Keterampilan kolaboratif memungkinkan dua orang atau lebih untuk mencapai sesuatu dengan hasil akhir yang dicapai, idealnya, lebih cepat dan/atau lebih baik daripada jika satu orang mencoba melakukannya sendiri.

Stephanie Harvey dan Daniels (2015) mengatakan bahwa ada beberapa cara para kolaborator yang mahir akan berpikir dan bertindak. 1) berbagi dan saling mendukung. 2) menunjukkan toleransi dan rasa hormat. 3) merenungkan dan mengevaluasi. 4) bertangung jawab. 5) mendengarkan secara aktif. 6) komunikasi. (Harney and daniels, 2015)

Dengan demikian keterampilan kolaborasi (collaborative skills) adalah proses interaksi antara beberapa orang untuk saling bekerjasama dan saling ketergantungan untuk mencapai tujuan bersama.

Secara etimologis, kata pedagogi berasal dari kata Yunani, paedos dan agogos ( aedos $=$ anak dan agoge $=$ mengantar atau membimbing). Karena itu pedagogi berarti 
membimbing anak, tugas membimbing ini melekat dalam tugas seorang pendidik, apakah guru atau orang tua.

Standar Akademik dan Kompetensi Guru menurut Permendiknas No. 16 Tahun 2007, kompetensi pedagogik terdiri dari: (1) menguasai karakteristik peserta didik dari aspek fisik, moral, spiritual, sosial, kultural, emosional, dan intelektual 2) menguasai teori belajar dan prinsip-prinsip pembelajaran yang mendidik 3) mengembangkan kurikulum yang terkait dengan mata pelajaran yang diampu 4) menyelenggarakan pembelajaran yang mendidik 5) memanfaatkan teknologi informasi dan komunikasi untuk kepentingan pembelajaran 6) Memfasilitasi pengembangan potensi peserta didik untuk mengaktualisasikan berbagai potensi yang dimiliki 7) berkomunikasi secara efektif, empatik, dan santun dengan peserta didik 8) menyelenggarakan penilaian dan evaluasi proses dan ahsil belajar 9) memanfaatkan hasil penilaian dan evaluasi untuk kepentingan pembelajaran 10) melakukan tindakan reflektif untuk peningkatan kualitas pembelajaran.

Sementara itu menurut Mulyasa (2011) menyatakan bahwa kompetensi pedagogik sangat penting karena menjadi penentu bagi keberhasilan proses belajar yang langsung menyentuh kemampuan pembelajaran meliputi pengelolaan peserta didik, perencanaan,

perencangan pelaksanaan, evaluasi hasil belajar dan pengembangan peserta didik terhadap potensi yang dimilikinya. (Mulyasa, 2011)

Dengan demikian kompetensi pedagogik merupakan kemampuan seorang guru dalam membimbing siswa dan seorang guru tidak hanya harus dapat memahami siswa tetapi tahu bagaimana caranya agar siswa dapat mengembangkan kelebihan dan kekurangannya.

Beberapa penelitianyang menggunakan variabel yang hampir sama yaitu hasil penelitian yang dilakukan oleh (Puspitasari, 2018). Universitas Negeri Yogyakarta dalam skripsinya yang berjudul: Peningkatan Collaboration Skill Siswa sebagai kecakapan Abad 21 Melalui Pembelajaran Model Cooperative Learning Tipe Team Accelerated Instruction (TAI) Mata Pelajaran IPA di SD Negeri Kotagede 1. Hasil penelitian yang dilakukan oleh: (Rubianto, 2016). Universitas Muhammadiyah Makassar dalam skripsinya yang berjudul Pengaruh Kompetensi Pedagogik Guru Terhadap Hasil Belajar Siswa pada Mata Pelajaran IPS SD Inpres Kecamatan Tallo Kota Makassar Tahun Pelajaran 2015/2016 yang menunjukkan bahwa variabel independent berpengaruh positif terhadap variabel dependen.

\section{METODE}

Penelitian ini dilakukan dengan menggunakan pendekatan penelitian deskriptif kuantitatif. Variabel yang digunakan dalam penelitian ini terdiri dari tiga variabel, yaitu variabel bebas dan variabel terikat. Variabel bebas yaitu collaborative skills $\left(\mathrm{X}_{1}\right)$, dan kompetensi pedagogik guru $\left(\mathrm{X}_{2}\right)$, variabel terikat adalah kinerja siswa (Y). Populasi dalam penelitian ini adalah guru sekolah dasar (SD) di Kecamatan Pamulang sebanyak 237 orang yang berada di gugus 10 . Untuk penelitian ini peneliti menggunakan teknik pengambilan sampel bertujuan atau Purposive Sampling, maka peneliti hanya mengambil sampel sebanyak 48 guru. Teknik pengumpulan data yang digunakan menggunakan angket. Angket yang akandisebar dalam penelitian ini adalah angket collaborative skills dan kompetensi pedagogik guru yang disusun berdasarkan definisi masing-masing dimensi variabel penelitian. 
http://ejurnal.pps.ungac.id/index.php/Aksara

Untuk instrument kinerja siswa, peneliti menggunakan nilai rata-rata kelas semester genap tahun pelajaran 2018/2019.

Metode analisis data dalam penelitian ini menggunakan Uji Product Moment Pearson Correlation pada uji validitas dan reabilitas. Untuk uji hipotesis menggunakan Uji Analisis Regresi Linier Berganda. Uji Product Moment Pearson Correlation bertujuan untuk menguji hubungan antara dua variabel yang menggunakan data berskala rasio atau interval. Peneltian Uji Analisis Regresi Linier Berganda bertujuan untuk mengetahui pengaruh variabel bebas yaitu collaborative skills $\left(\mathrm{X}_{1}\right)$ serta kompetensi pedagogik guru $\left(\mathrm{X}_{2}\right)$ secara keseluruhan terhadap variabel terikat yaitu kinerja siswa $(\mathrm{Y})$. Penelitian ini juga menggunakan Teknik analisis faktor dengan menggunakan Teknik Second Order Confirmatory Faktor Analysis ( $2^{\text {nd }} \mathrm{CFA}$ ) dengan tujuan untuk menentukan dimensi yang paling besar kontribusinya terhadap masing-masing variabel.

\section{HASIL DAN PEMBAHASAN HASIL}

Untuk mengetahui pengaruh kedua variabel bebas terhadap variabel terikat, maka peneliti menggunakan statistik uji t. pengujian dilakukan dengan menggunakan program software SPSS IBM 23. Hasil pengujian yang dilakukan dapat diamati pada tabel 1.1 berikut ini:

Tabel 1.1

Hasil Uji T-Tabel Coefficients $^{\mathrm{a}}$

\begin{tabular}{|c|c|c|c|c|c|}
\hline \multirow[b]{2}{*}{ Model } & \multicolumn{2}{|c|}{ Unstandardized Coefficients } & \multirow{2}{*}{$\begin{array}{c}\begin{array}{c}\text { Standardized } \\
\text { Coefficients }\end{array} \\
\text { Beta }\end{array}$} & \multirow[b]{2}{*}{$\mathrm{t}$} & \multirow[b]{2}{*}{ Sig. } \\
\hline & $\mathrm{B}$ & Std. Error & & & \\
\hline 1 (Constant) & $9 . .342$ & 14.412 & & .648 & .520 \\
\hline Collaborative Skills & .269 & .120 & .269 & 2.233 & .031 \\
\hline Kompetensi Pedagogik Guru & .343 & .081 & .510 & 4.239 & .000 \\
\hline
\end{tabular}

a. Dependent Variable: Kinerja Siswa

Berdasarkan tabel 1.1 dapat dilihat bahwa pengujian statistik dengan metode uji t diperoleh hasil sebagai berikut:

a. Pengujian Hipotesis Pertama $\left(\mathrm{H}_{1}\right)$

Diketahui Sig untuk pengaruh $\mathrm{X}_{1}$ terhadap Y adalah sebesar 0,031<0,05 dan nilai thitung 2,233 > t table 2,012. Sehingga dapat disimpulkan bahwa $\mathrm{H}_{1}$ diterima yang berarti terdapat pengaruh $\mathrm{X}_{1}$ terhadap $\mathrm{Y}$. Hal ini berarti collaborative skills berpengaruh signifikan dan positif terhadap kinerja siswa.

b. Pengujian Hipotesis Kedua $\left(\mathrm{H}_{2}\right)$

Diketahui Sig untuk pengaruh $\mathrm{X}_{2}$ terhadap $\mathrm{Y}$ adalah sebesar $0,000<0,05$ dan nilai t hitung 4,239>t table 2,012. Sehingga dapat disimpulkan bahwa $\mathrm{H}_{2}$ diterima yang berarti terdapat pengaruh $\mathrm{X}_{2}$ terhadap $\mathrm{Y}$. Hal ini berarti kompetensipedagogik guru berpengaruh signifikan dan positif terhadap kinerja siswa.

Untuk mengetahui pengaruh kedua variabel bebas terhadap variabel terikat, maka peneliti menggunakan statistik uji F. Pengujian dilakukan dengan menggunakan program software SPSS IBM 23. Hasil pengujian yang dilakukan dapat diamati pada tabel 1.2 berikut ini: 


\section{c. Uji Anova}

Tabel 1.2

\section{Hasil Uji Anova}

ANOVA $^{\text {a }}$

\begin{tabular}{|l|r|r|r|c|c|}
\hline Model & Sum of Squares & df & Mean Square & F & Sig. \\
\hline 1 Regression & 333.320 & 2 & 166.660 & 17.058 & $.000 \mathrm{~b}$ \\
Residuall & 439.659 & 45 & 9.770 & & \\
Total & 772.979 & 47 & & & \\
\hline
\end{tabular}

a. Dependent Variable: Kinerja Siswa

b. Predictors: (Constant), Kompetensi Pedagogik Guru, Collaborative Skills

\section{d. Pengujian Hipotesis Ketiga $\left(\mathrm{H}_{3}\right)$}

Berdasarkan tabel 1.3 diketahui nilai signifikasi untuk pengaruh $\mathrm{X}_{1}$ dan $\mathrm{X}_{2}$ secara simultan terhadap $\mathrm{Y}$ adalah $0,000<0,05$ dan nilai Fhitung $17.058>\mathrm{F}_{\text {tabel }}$ 3,20. Sehingga dapat disimpulkan bahwa $\mathrm{H}_{3}$ diterima yang berarti terdapat pengaruh $\mathrm{X}_{1}$ dan $\mathrm{X}_{2}$ secara simultan terhadap $\mathrm{Y}$. Hal ini bahwa adanya pengaruh positif dan signifikan antara collaborative skills dan kompetensi pedagogik guru secara bersama-sama berpengaruh positif dan signifikan terhadap kinerja siswa.

Untuk mengetahui Uji Koefisien Determinasi (Adjused R Square) dilakukan pada kedua variabel bebas dan variabel terikat. Hasil uji koefisien Determinasi dapat diamati pada tabel 1.3 berikut:

\section{Tabel $\quad 1.3$}

Hasil Uji R-Square

\begin{tabular}{|l|r|r|r|r|r|}
\hline Model & \multicolumn{1}{|c|}{ Model Summary $^{\mathbf{b}}$} \\
\hline 1 & $.657^{\mathrm{a}}$ & R Square & $\begin{array}{c}\text { Adjusted R } \\
\text { Square }\end{array}$ & $\begin{array}{c}\text { Std. Error of the } \\
\text { Estimate }\end{array}$ & Durbin-Watson \\
\hline
\end{tabular}

a. Predictors: (Constant), Kompetensi Pedagogik Guru, Collaborative Skills

b. Dependent Variable: Kinerja Siswa

Berdasarkan hasil pada tabel 1.3 menunjukkan bahwa bahwa nilai koefisien determinasi yang dinyatakan dalam Dari tabel di atas, dapat disimpulkan bahwa besarannya collaborative skills serta kompetensi pedagogik guru terhadap kinerja siswa sebesar 0.431 atau $43.1 \%$ dan sisanya sebesar $56.9 \%$ ditentukan oleh variabel lain yang tidak dimasukkan dalam penelitian ini.

\section{ANALISIS FAKTOR}

\section{Analisis Faktor Untuk Indikator Collaborative Skills}

Tujuan dari analisa factor dengan menggunakan $2^{\text {nd }}$ CFA (Confirmataory Factor Analysis) adalah menentukan dimensi yang paling besar kontribusinya terhadap Collaborative skills (X1). Berikut adalah hasil gambar loading factor $2^{\text {nd }}$ CFA dan tabulasi dari 6 dimensi pembentuk variabel collaborative skills. 
AKSARA: Jurnal Ilmu Pendidikan Nonformal

P-ISSN 2407-8018 E-ISSN 2721-7310 DOI prefix $\underline{10.37905}$

Volume 07 (02) Mei 2021

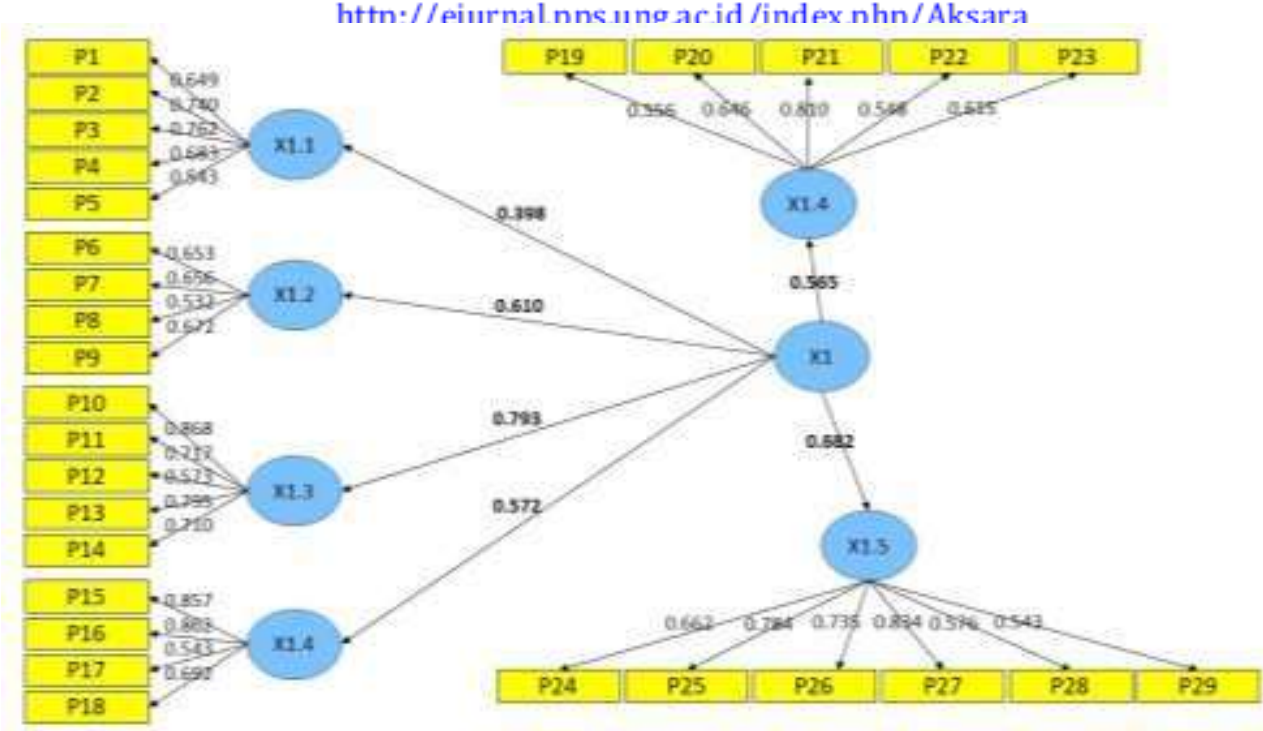

Gambar 1.1

Hasil $2^{\text {nd }}$ CFA

Variabel Collaborative Skills (X1)

Hasil dimensi menunjukkan bahwa kontribusi tertinggi sampai terendah jika diurutkan maka dimensi tertinggi yaitu merenungkan dan mengevaluasi(X1.3). Selanjutnya untuk kontribusi loading factor dimensi lainnya adalah dimensi menunjukkan toleransi dan rasa hormat(X1.2), dimensi bertanggung jawab(X1.4), dimensi mendengarkan secara aktif(X1.5), dan dimensi komunikasi(X1.6). Sedangkan dimensi terendah adalah berbagi dan saling mendukung (X1.1). Hal tersebut mengindikasikan bahwa untuk dimensi dengan nilai loading terendah menjadi perhatian untuk prioritas ditingkatkan agar mampu meningkatkan X1.

\section{Analisis Faktor Untuk Indikator Kompetensi Pedagogik Guru}

Tujuan dari Analisa factor dengan menggunakan $2^{\text {nd }}$ CFA (Confirmataory Factor Analysis) adalah menentukan dimensi yang paling besar kontribusinya terhadap kompetensi pedagogik guru (X2). Berikut adalah hasil gambar loading factor $2^{\text {nd }}$ CFA dan 8 dimensi pembentuk variabel kompetensi pedagogik guru (X2). 


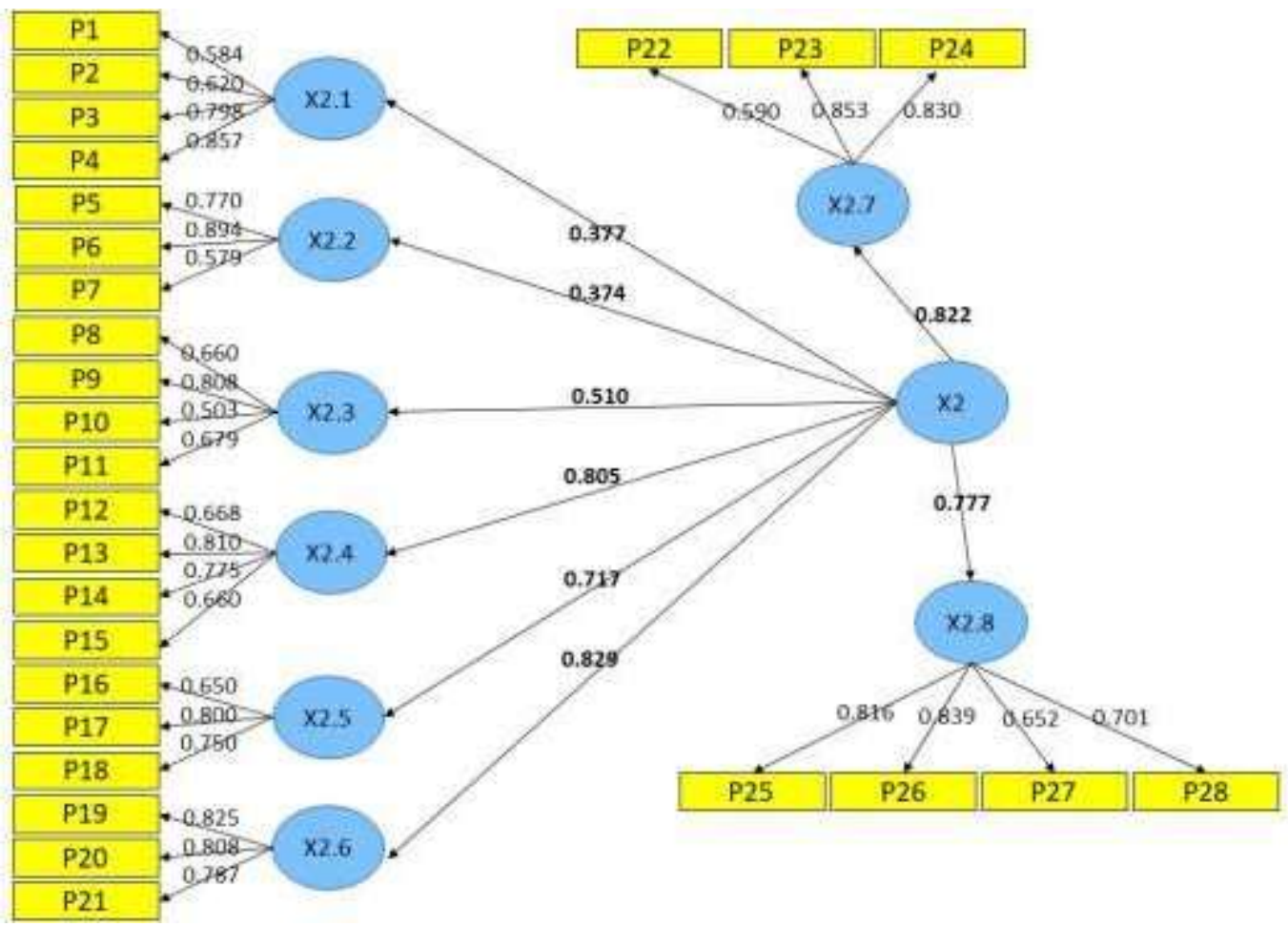

Gambar 1.2

Hasil $2^{\text {nd }} C F A$

Variabel Kompetensi Pedagogik Guru (X2)

Hasil dimensi menunjukkan bahwa kontribusi tertinggi sampai terendah jika diurutkan maka dimensi tertinggi yaitu mengembangkan potensi peserta didik (X2.6). Sedangkan untuk kontribusi loading factor dimensi lainnya adalah dimensi menguasai karakteristik peserta didik (X2.1), dimensi mengembangkan kurikulum (X2.3), dimensi kegiatan pembelajaran yang mendidik (X2.4), dimensi memanfaatkan teknologi informasi (X2.5), dimensi komunikasi dengan peserta didik (X27), dan penilaian dan evaluasi(X28). Untuk dimensi terendah adalah menguasai teori belajar dan prinsip-prinsip pembelajaran yang mendidik (X2.2). Hal tersebut mengindikasikan bahwa untuk dimensi dengan nilai loading terendah menjadi perhatian untuk prioritas ditingkatkan agar mampu meningkatkan X2.

\section{Pembahasan Hasil Penelitian}

Hasil analisis pengaruh collaborative skills dan kompetensi pedagogik guru terhadap kinerja siswa sekolah dasar di gugus 10 Kecamatan Pamulang baik secara deskriptif dengan menggunakan analisis tabel maupun dengan analisis statistik dapat peneliti jelaskan di bawah ini. 


\section{AKSARA: Jurnal Ilmu Pendidikan Nonformal}

P-ISSN 2407-8018 E-ISSN 2721-7310 DOI prefix $\underline{10.37905}$

Volume 07 (02) Mei 2021

\section{Pengaruh Collaborative Skills Terhadap Kinerja Siswa}

http://ejurnal.pps.ungac.id/index.php/Aksara

Dari hasil pengujian, variabel collaborative skills memiliki pengaruh atau hubungan dengan variabel kinerja siswa. Hal ini ditunjukkan dengan koefisien variabel dimana collaborative skills berpengaruh positif sebesar 0,269 dan juga hasil hipotesis yang menunjukkan nilai thitung sebesar 2.233 lebih besar dari tabel $(\mathrm{df}=46, \alpha=0,05)$ sebesar 2,012 atau 2.233>2,012. Selain itu, diketahui nilai sig sebesar 0,031 dimana nilai sig lebih kecil dari 0,05 atau 0,740 >0,05. Dengan demikian dapat disimpulkan bahwa collaborative skills berpengaruh terhadap kinerja siswa sekolah dasar di gugus 10 Kecamatan Pamulang

Collaborative skills merupakan salah satu keterampilan yang harus dimiliki oleh seorang guru di abad 21, kolaborasi menjadi hal yang sangat penting di dalam dunia pendidikan, karena dengan adanya kolaborasi atau interaksi yang baik antara guru dengan siswa dapat berdampak baik dalam proses belajar mengajar di dalam kelas selain itu hubungan yang harmonis antara guru dengan siswa juga akan berdampak pada hasil akademik siswa.

Selain kolaborasi antara guru dengan siswa, kolaborasi antar guru pun harus terjalin dengan baik misalnya dengan saling berdiskusi antar guru dalam menyiapkan strategi mengajar yang baik, atau guru diobservasi oleh guru lain pada saat mereka mengajar di kelas. Dengan adanya observasi guru, guru akan bisa menerima saran dan kritik yang baik, sehingga diharapkan dapat meningkatkan mutu pembelajaran semua guru dan dengan adanya kolaborasi yang baik antar guru akan bermanfaat untuk menemukan gagasan baru untuk meningkatkan kemampuan diri.

Adanya pengaruh yang signifikan collaborative skills guru terhadap kinerja siswa membuktikan bahwa teori yang menyatakan collaborative skills dapat meningkatkan kinerja siswa sejalan dengan kerangka berpikir yang diajukan. Dengan demikian, lewat penelitian ini terbukti bahwa collaborative skills merupakan salah satu faktor penentu bagi meningkatnya kinerja siswa, disamping faktor-faktor lainnya.

\section{Pengaruh Kompetensi Pedagogik Guru Terhadap Kinerja Siswa}

Berdasarkan hasil uji hipotesis mengenai pengaruh kompetensi pedagogik guru ternyata memiliki pengaruh terhadap kinerja siswa. Hal ini ditunjukkan dimana kompetensi pedagogik guru berpengaruh positif sebesar 0,343 , dan juga hasil uji hipotesis yang menunjukkan nilai thitung sebesar 4,239 lebih besar dari tabel $(\mathrm{df}=46, \alpha$ $=0,05$ ) sebesar 2,012 atau 4,239 > 2,012. Selain itu, nilai sig sebesar 0,000 dimana nilai sig lebih kecil dari 0,05 atau $0,000<0,05$. Ini berarti $\mathrm{H}_{0}$ ditolak dan dapat disimpulkan bahwa kompetensi pedagogik guru berpengaruh terhadap kinerja siswa sekolah dasar di gugus 10 Kecamatan Pamulang.

Kompetensi pedagogik guru merupakan kemampuan guru yang berkaitan langsung dengan peserta didik selama proses belajar mengajar berlangsung. Guru harus mampu mengoptimalkan potensi peserta didik untuk mengaktualisasikan kemampuannya di kelas, dan harus mampu melakukan penilaian terhadap kegiatan pembelajaran yang telah dilakukan.

Adanya pengaruh yang signifikan kompetensi pedagogik guru terhadap kinerja siswa membuktikan bahwa teori yang menyatakan kompetensi pedagogik guru dapat meningkatkan kinerja siswa sejalan dengan kerangka berpikir yang diajukan. Dengan demikian, lewat penelitian ini terbukti bahwa kompetensi pedagogik guru merupakan 
AKSARA: Jurnal Ilmu Pendidikan Nonformal

P-ISSN $\underline{2407-8018}$ E-ISSN $\underline{2721-7310}$ DOI prefix $\underline{10.37905}$

Volume 07 (02) Mei 2021

salah satu faktor penentu bagi meningkatnya Kimerja siswa, disamping faktor-faktor lainnya.

3. Pengaruh Collaborative Skills dan Kompetensi Pedagogik Guru Terhadap Kinerja Siswa

Berdasarkan hasil uji hipotesis, terdapat pengaruh antara collaborative skills dan kompetensi pedagogik guru bersama-sama terhadap kinerja siswa. Hal ini dapat dilihat dari hasil uji hipotesis yang menunjukkan nilai Fhitung lebih besar dari $\mathrm{F}_{\text {tabel }}$ (df1=2 df $2=46, \alpha=0,05$ ) sebesar 3,20 atau 17,058 $>3,20$. Selain itu, diketahui nilai sig sebesar $0,000<0,05$. Dengan demikian dapat disintesakan bahwa $\mathrm{H}_{\mathrm{o}}$ ditolak dan dapat disimpulkan bahwa collaborative skills dan kompetensi pedagogik guru berpengaruh terhadap kinerja siswa sekolah dasar di gugus 10 Kecamatan Pamulang.

4. Hasil analisis $2^{\text {nd }}$ CFA menunjukkan bahwa dimensi pengukur variabel X1 yaitu collaborative skills pada kontribusi dimensi tertinggi yaitu merenungkan dan mengevaluasi(X1.3) dengan loading factor sebesar 0.793 dan dimensi terendah adalah berbagi dan saling mendukung(X1.1) dengan loading factor sbesar 0.398. hal tersebut mengindikasikan bahwa untuk dimensi dengan nilai loading terendah menjadi perhatian untuk prioritas ditingkatkan agar mampu meningkatkan X1.

5. Hasil analisis $2^{\text {nd }}$ CFA menunjukkan bahwa dimensi pengukur variabel $X 2$ yaitu kompetensi pedagogik guru pada kontribusi dimensi tertinggi yaitu mengembangkan potensi peserta didik (X2.6) dengan loading factor sebesar 0.829 dan dimensi terendah adalah menguasai teori belajar dan prinsip-prinsip pembelajaran yang mendidik (X2.2) dengan loading factor sbesar 0.374. Hal tersebut mengindikasikan bahwa untuk dimensi dengan nilai loading terendah menjadi perhatian untuk prioritas ditingkatkan agar mampu meningkatkan X2.

\section{PENUTUP}

Berdasarkan hasil penelitian dan pembahasan pada bab sebelumnya, maka dapat diambil kesimpulan sebagai berikut:

1. Terdapat pengaruh yang signifikan antara variabel collaborative skills terhadap kinerja siswa mengandung arti semakin tinggi collaborative skills guru, maka semakin baik pula kinerja siswanya. Begitu juga sebaliknya semakin rendah collaborative skills guru maka semakin rendah kinerja siswanya.

2. Terdapat pengaruh yang signifikan antara variabel kompetensi pedagogik guru terhadap kinerja siswa mengandung arti bahwa semakin baik kimpetensi pedagogik guru, maka semakin baik kinerja siswanya.

3. Terdapat pengaruh signifikan antara collaborative skills dan kompetensi pedagogik guru bersama-sama terhadap kinerja siswa mengandung arti bahwa semakin tinggi tingkat collaborative skills guru dan kompetensi pedagogik guru, maka semakin baik pula kinerja siswanya.

\section{Daftar Pustaka}

Daryanto, S. K. dan. (2017). Pembelajaran Abad 21 (cetakan pertama). Yogyakarta: Gava Media.

Harney and daniels, S. (2015). Comprehension and collaboration, Reviced Edition. UK: Heinemann.

Jhon and Wiles Kimball, L. (1983). Supervision for Better Schools (Fifth Edit). New Jersey: Prentice-Hall.

534 AKSARA: Jurnal Ilmu Pendidikan Nonformal 
Koesmono. (2013). PengaruhtpBudavea Onganisasid/erhoddpp/Motivasi Dan Kepuasan Kerja Serta Kinerja Karyawan Pada Sub Sektor Industri Pengolahan Kayu Skala Menengah Di Jawa Timur. 7(2), 162-179.

Leonard, L. (2013). Peran Kemampuan Berpikir Lateral Dan Positif Terhadap Prestasi Belajar Evaluasi Pendidikan. Jurnal Cakrawala Pendidikan, 5(1), 54-63. https://doi.org/10.21831/cp.v5i1.1259

Mulyasa. (2011). Standar Kompetensi dan Sertifikasi Guru (cetakan ke-5). Bandung: Remaja Rosdakarya.

Priansa, D. J. (2014). Kinerja dan Profesional Guru. Bandung: Alfabeta.

Puspitasari, N. (2018). Peningkatan Collaboration Skill Sisiwa Sebagai Kecakapan Abad 21 melalui Pembelajaran Model Cooprative Learning Tipe Team Accelerated Instruction (TAI) Mata Pelajaran IPA di SD Negeri Kotagede1.

Rubianto. (2016). Pengaruh Kompetensi Pedagogik Guru terhadap Hasil belajar siswa pada Mata Pwlajaran IPS SD Inpres Kecamatan Tallo Kota Makassar Tahun Ajaran 2015/2016.

Undang-Undang-Nomor-14-Tahun-2005.pdf. (2005). 
AKSARA: Jurnal Ilmu Pendidikan Nonformal

P-ISSN 2407-8018 E-ISSN 2721-7310 DOI prefix $\underline{10.37905}$

Volume 07 (02) Mei 2021

http://ejurnal.pps.ungac.id/index.php/Aksara 